\title{
REKONSTRUKSI PELAKSANAAN EKSEKUSI JAMINAN FIDUSIA PASCA PUTUSAN MAHKAMAH KONSTITUSI NOMOR 18/PUU-XVII/2019
}

Joni Alizon, Dosen Pada Program Studi Ilmu Hukum Universitas Islam Negeri Sultan SyarifKasim Riau.

Email: joni_alizon@yahoo.com

\begin{abstract}
The implementation of Article 15 paragraph (2) and paragraph (3) of the Fiduciary Security Act relating to the execution of fiduciary guarantees in practice raises the creditor's arbitrariness when collecting, withdrawing fiduciary collateral objects (movable objects) under the pretext of the debtor in breach of promise. at the time of the breach of promise there was no explanation in Article 15 of the Fiduciary Security Act. In consideration of the Constitutional Court Decision Number 18 / PUU-XVII / 2019 it was explained that the breach of the promise must be made agreed by the parties. If the parties do not have an agreement, then the execution of the execution through a court decision in accordance with HIR and RBg. Thus, the issue of breach of contract in the execution of fiduciary guarantees is not immediately resolved through the court. However, the parties' agreement must be preceded to determine when the alleged breach of the allegation occurred. If there is an agreement between the parties, the creditor can immediately execute. The Constitutional Court further stated that Article 15 paragraph (2) of the Fiduciary Guarantee Law on the phrase "executive power" and the phrase "equals a court decision that has permanent legal force" is unconstitutional as long as it does not mean fiduciary guarantees for which there is no breach of agreement (default agreement) and the debtor object to objection voluntarily surrender the object of fiduciary guarantee, then all the legal mechanisms and procedures for the execution of the execution of the Fiduciary Guarantee Certificate must be carried out and in effect the same as the execution of a court decision that has permanent legal force.
\end{abstract}

Keywords: Execution, Guarantee, Fiduciary

\begin{abstract}
Abstrak
Implementasi Pasal 15 ayat (2) dan ayat (3) Undang-undang Jaminan Fidusia terkait eksekusi jaminan fidusia dalam praktiknya menimbulkan kesewenang-wenangan kreditur ketika menagih, menarik objek jaminan fidusia (benda bergerak) dengan dalih debitur cidera janji. waktu terjadinya cidera janji tersebut tidak ada penjelasan dalam Pasal 15 Undang-undang Jaminan Fidusia itu, Dalam pertimbangan Putusan Mahkamah Konstitusi
\end{abstract}


Nomor 18/PUU-XVII/2019 dijelaskan, bahwa cidera janji harus dibuat dan disepakati para pihak. Kalau para pihak tidak ada kesepakatan, maka pelaksanaan eksekusi melalui putusan pengadilan sesuai HIR dan $\mathrm{RBg}$.Dengan demikian, persoalan cidera janji dalam eksekusi jaminan fidusia tidak langsung diselesaikan melalui pengadilan. Namun, harus didahului kesepakatan para pihak untuk menentukan kapan terjadinya tuduhan cidera janji tersebut. Jika sudah ada kesepakatan para pihak, kreditur dapat langsung mengeksekusi. Lebih lanjut Mahkamah Konstitusi menyatakan Pasal 15 ayat (2) UU Jaminan Fidusia frasa "kekuatan eksekutorial" dan frasa "sama dengan putusan pengadilan yang berkekuatan hukum tetap" inkonstitusional sepanjang tidak dimaknai terhadap jaminan fidusia yang tidak ada kesepakatan cidera janji (wanprestasi) dan debitur keberatan menyerahkan secara sukarela objek jaminan fidusia, maka segala mekanisme dan prosedur hukum pelaksanaan eksekusi Sertifikat Jaminan Fidusia harus dilakukan dan berlaku sama dengan pelaksanaan eksekusi putusan pengadilan yang telah berkekuatan hukum tetap.

\section{Kata kunci: Eksekusi, Jaminan, Fidusia}

\section{Pendahuluan}

Berdasarkan Undang-Undang No. 42 Tahun 1999 Tentang Jaminan Fidusia, adanya hak eksekusi atau kekuatan eksekutorial adalah pelaksananaan eksekusi yang langsung dapat dilaksanakan tanpa melalui pengadilan dan bersifat final serta mengikat para pihak untuk melaksanakan putusan tersebut. Tentunya mengenai aturan tersebut banyak masyarakat belum mengetahui dan hanya pasrah jika pelaku usaha atau debt collector mengambil kendaraannya secara paksa. Disisi lain Undang-Undang No. 8 Tahun 1999 Tentang Perlindungan Konsumen, menyatakan konsumen berhak mendapatkan perlindungan hukum jika terjadi cidera janji yang dilakukan oleh pelaku usaha dalam hal ini atas pengambilan paksa kendaraan konsumen yang belum jatuh tempo. Mengenai permasalahan tersebut bentuk perlindungan konsumen atas eksekusi kendaraan yang belum jatuh tempo yakni diatur berdasarkan Undang-Undang No. 8 Tahun 1999 Tentang Perlindungan Konsemen. Bahwa Konsumen dilindungi oleh ketentuan Undang-Undang No. 8 Tahun 1999 Tentang Perlindungan Konsumen. Pemerintah memiliki tugas untuk membina dan melakukan pengawasan terhadap perlindungan konsumen, 
mengenai tentang penarikan kendaraan bermotor yang diduga melakukan pelanggaran adanya aturan hukum yang mengatur yakni Undang-Undang Jaminan Fidusia dan Peraturan Menteri Keuangan. Pembiayaan sama seperti kredit konsumen, yang membedakan yakni pada lembaga yang membiayainya. Pembiayaan konsumen adalah biaya yang diberikan oleh perusahaan pembiayaan (financing company), sedangkan kredit konsumen diberikan oleh bank. ${ }^{1}$

Bahwa Pasal 15 Undang-Undang No.42 Tahun 1999 Tentang Jaminan Fidusia yang pada intinya jika konsumen (debitur) tidak mampu membayar maka finance diberikan kuasa untuk mengambil kendaraan dimanapun dan kapanpun yang kemudian ditanda tangani oleh konsumen. Kita mengenal lembaga pembiayaan yakni sebagai badan usaha yang melakukan kegiatan pembiayaan dalam bentuk penyediaan dana atau barang modal. Lembaga Pembiayaan merupakan alternatif pembiayaan diluar perbankan yang lebih dapat disesuaikan dengan kebutuhan riil di masyarakat bisnis. ${ }^{2}$ Dalam pengambilan kendaraan bermotor jika sudah ada perjanjian fidusia, kemudian dibuatkan akte notarisnya bahwa jelas dalam hal ini finance sudah memenuhi aturannya dalam penarikan kendaraan. Tetapi dalam kenyataannya kebanyakan pihak finance tidak mematuhi aturan-aturan tersebut seperti tidak menyertakan jaminan fidusianya bahkan ada juga yang diduga palsu dalam pengambilan kendaraan.

Beberapa permasalahan yang timbul dari Lembaga Jaminan Fidusia, yaitu:

a. Permasalahan eksekusi jaminan fidusia Walaupun dalam Pasal 29 No. 42 Tahun 1999 tentang Jaminan Fidusia telah diatur mengenai eksekusi objek jaminan fidusia, akan tetapi dalam pelaksanaannya hal tersebut sangat sulit untuk

\footnotetext{
${ }^{1}$ Sunaryo, Hukum Lembaga Pembiayaan, Sinar Grafika, Jakarta, 2007, hlm. 96.

${ }^{2}$ Khotibul Umam, , Hukum Lembaga Pembiayaan, Pustaka Yustisia, Yogyakarta, 2010. hlm. 2.
} 
dilaksanakan. Begitu besarnya campur tangan badan peradilan membuat eksekusi memakan waktu yang lama dan memakan banyak biaya. Padahal nilai dari barang-barang bergerak semakin menyusut, sehingga seharusnya eksekusi dapat dilaksanakan dengan proses yang sederhana, waktu yang cepat dan biaya murah. Selain itu dalam pelaksanaan eksekusi, hak lain yang diberikan Undang-Undang No.42 Tahun 1999 kepada kreditur penerima fidusia adalah untuk menguasai objek jaminan fidusia. Akan tetapi ketentuan dalam Pasal 30 kurang efektif karena tidak ada sanksi bagi pemberi fidusia yang tidak mau menyerahkan objek jaminan fidusia.Walaupun ditentukan bahwa penerima fidusia dapat meminta bantuan dari pihak yang berwenang. Hal ini dikeluhkan perusahaan pembiayaan mengingat tingginya biaya yang harus dikeluarkan jika meminta bantuan polisi.

b. Kesulitan untuk menjaga dan memeriksa keutuhan objek jaminan fidusia baik jumlah maupun kualitasnya. Pihak perusahaan pembiayaan mengakui sulitnya untuk melakukan pengawasan terhadap benda yang menjadi objek jaminan fidusia.

c. Nilai benda bergerak tersebut cenderung semakin menyusut.

Kekurangan-kekurangan tersebut menyebabkan lembaga jaminan fidusia kurang dapat berperan dibandingkan dengan lembaga hak tanggungan. Dalam upaya meningkatkan pelayanan kepada masyarakat, perlu dipikirkan kembali cara meningkatkan peranan jaminan fidusia. Salah satu permasalahan yang harus dipecahkan adalah pelaksanaan eksekusi jaminan fidusia pasca Mahkamah Konstitusi mengabulkan uji materi terhadap Pasal 15 ayat (2), dan ayat (3) undang-undang Nomor 42 Tahun 1999 tentang Jaminan Fidusia terkait sertifikat jaminan fidusia yang memiliki kekuatan eksekutorial. Artinya, jika debitur (konsumen) cidera/ingkar janji (wanprestasi), penerima fidusia (perusahaan leasing) punya hak menjual objek jaminan dengan kekuasaannya sendiri (lelang). Namun, Mahkamah Konstitusi memutuskan sertifikat jaminan fidusia tidak 
serta merta (otomatis) memiliki kekuatan eksekutorial. Selain itu, cidera janji dalam eksekusi perjanjian fidusia harus didasarkan pada kesepakatan kedua pihak antara debitur dan kreditur atau atas dasar upaya hukum (gugatan ke pengadilan) yang menentukan telah terjadinya cidera janji

\section{Kajian Pustaka}

Istilah fidusia berasal dari Bahasa Belanda, yaitu fiducie, sedangkan dalam Bahasa Inggris disebut fiduciary transfer of ownership, yang artinya kepercayaan Fidusia merupakan istilah yang sudah lama dikenal dalam bahasa Indonesia. Undang-undang Jaminan Fiidsia No. 42 Tahun 1999 sudah menggunakan istilah "fidusia". Dengan demikian, istilah "fidusia" sudah merupakan istilah resmi dalam dunia hukum, akan tetapi, kadang-kadang untuk fidusia ini dalam bahasa Indonesia disebut juga dengan istilah "penyerahan hak milik secara kepercayaan". Dalam terminologi Belandanya sering disebut dengan istilah lengkapnya yaitu fiduciare eigendom overdracht, sedangkan dalam bahasa Inggrisnya secara lengkap sering disebut fiduciary transfer of ownership. ${ }^{3}$

Cirikhas dari Jaminan fidusia adalah dengan adanya tindakan eksekutorial melalui proses parate eksekusi yaitu kewenangan yang dimiliki kreditur untuk menjual barang jaminan dimuka umum bila debitur wanprestasi tanpa ada fiat atau ijin Ketua Pengadilan Negeri. Dengan adanya ketentuan tersebut memberikan kemudahan kepada kreditur dibandingkan cara eksekusi dengan cara lain dan tentunya memberikan perlindungan hukum terhadap hak-hak kreditur penerima fidusia apabila debitur cidera janji. ${ }^{4}$ Sebagaimana diatur dalam pasal 15 undang-undang Jaminan Fidusia yang menyatakan:

\footnotetext{
${ }^{3}$ Salim HS, Perkembangan Hukum Jaminan di Indonesia, RajaGrafindo Persada, Jakarta, 2008, hlm. 23

${ }^{4}$ Rachmadi Usman, Hukum Jaminan Keperdataan, Jakarta Sinar Grafika, 2008. hlm. 229.
} 
1. Dalam Sertifikat Jaminan Fidusia sebagaimana dimaksud dalam Pasal 14 ayat (1) dicantumkan kata-kata "DEMI KEADILAN BERDASARKAN KETUHANAN YANG MAHA ESA".

2. Sertifikat Jaminan Fidusia sebagaimana dimaksud dalam ayat (1) mempunyai kekuatan eksekutorial yang sama dengan putusan pengadilan yang telah memperoleh kekuatan hukum tetap;

3. Apabila debitur cidera janji, Penerima Fidusia mempunyai hak untuk menjual Benda yang menjadi objek Jaminan Fidusia atas kekuasaannya sendiri.

Dalam perkembangannya aturan tersebut diatas dianggap bermasalah karena telah memberi Kekuasaan yang berlebihan kepada Kreditur dan tanpa kontrol mekanisme hukum yang sewajarnya, dengan menyetarakan kedudukan Sertifikat Jaminan Fidusia dengan putusan pengadilan berkekuatan hukum tetap, telah mengakibatkan tindakan sewenang-wenang Penerima Fidusia untuk melakukan eksekusi terhadap objek jaminan fidusia, bahkan dengan menghalalkan segala macam cara serta tanpa melalui prosedur hukum yang benar. Tindakan sewenang-wenang yang dilakukan Penerima Fidusia dilakukan dengan cara menyewa jasa debt collector, untuk mengambil alih barang yang dikuasai Debitur tanpa melalui prosedur hukum yang benar. Ada beberapa momentum tindakan paksa, tanpa menunjukkan bukti dan dokumen resmi, tanpa kewenangan, dengan menyerang diri pribadi, kehormatan, harkat dan martabat, serta mengancam.

Penarikan dengan paksa dilakukan penagih utang (debt collector) sebagai Kuasa kreditor merupakan pelanggaran hukum dan sebagai tindakan melawan hukum jika dilakukan tanpa menunjukkan surat fidusia. Hal tersebut bertentangan dengan pasal 3 Peraturan Menteri Keuangan No.130 / PMK.010 / 2012 dan penjelasan Pasal 30 Undang-Undang

${ }^{5}$ Pasal 3 Peraturan Menteri Keuangan No.130 / PMK.010 / 2012 menyatakan “ Perusahaan pembiayaan dilarang melakukan penarikan objek jaminan fidusia berupa kendaraan bermotor apabila kantor pendaftaran fidusia belum menerbitkan sertifikat fidusia dan menyerahkan kepada perusahaan pembiayaan". 
Nomor 42 Tahun 1999 tentang Jaminan Fidusia yang menyatakan bahwa penerima fidusia dapat meminta bantuan pihak berwenang jika pemberi fidusia tidak menyerahkan objek fidusia. ${ }^{6}$ Pihak pihak yang berwenang dalam hal ini adalah kepolisian. ${ }^{7}$

Eksekusi tidak hanya berkaitan dengan putusan pengadilan dan grosse akta, akan tetapi istilah eksekusi juga terdapat di dalam bidang hukum jaminan. Eksekusi objek jaminan yang merupakan pelaksanaan hak kreditur pemegang hak jaminan terhadap objek jaminan, apabila debitur cedera janji atau wanprestasi dengan cara penjualan obyek jaminan untuk pelunasan hutangnya.

Eksekusi terhadap objek jaminan, selain berdasarkan kepada pasal 224HIR/258 RBg terdapat juga pengaturan yang khususnya terhadap pelaksanaan hak-hak jaminan, dimana kreditur diberi hak khusus, yakni hak menjual atas kekuasaan sendiri apabila debitur cidera janji dikenal juga dengan nama parate executie atau eksekusi langsung. Parate executie merupakan hak kreditur pertama untuk menjual barang-barang tertentu milik debitur secara lelang tanpa terlebih dahulu mendapatkan fiat pengadilan. ${ }^{8}$ Pengaturan parate executie diatur secara khusus, seperti yang terdapat dalam Pasal 1155 KUHPerdata tentang Gadai, pasal 6 Undang-Undang Nomor 4Tahun 1996 Tentang Hak Tanggungan dan Pasal 29 ayat (1) Undang-undang Nomor 42 Tahun 1999 Tentang Jaminan Fidusia.

\footnotetext{
${ }^{6}$ Pasal 30 Undang-undang jaminan Fidusia "pemberi fidusia ( berhutang) wajib menyerahkan benda yang menjadi objek jaminan fidusia dalam rangka pelaksanaan eksekusi", selanjutnya penjelasan pasal 30 " dalam hal pemberi fidusia tidak menyerahkan objek jaminan fidusia pada eksekusi dilaaksanakan, penerima fidusia berhak mengambil benda yang menjadi objek jaminan fidusia, apabila perlu dapat meminta bantuan pihak berwenag"

${ }^{7}$ Shavira Ramadhanneswari, "Penarikan Kendaraan Bermotor Oleh Perusahaan Pembiayaan Terhadap Debitur Yang Mengalami Kredit Macet (Wanprestasi) Dengan Jaminan Fidusia Ditinjau Dari Aspek Yuridis" Jurnal IImiah Fakultas Hukum, Universitas Diponegoro, 2017,hlm.3.

8 Herowati Poesoko, Parate Executie Obyek Hak Tanggungan, Yogyakarta: Laksbang Pressindo, cetakan. II, 2008, hlm. 125.
} 
Menurut Yahya Harahap, ada beberapa bentuk pengecualian yang dibenarkan undang-undang yang memperkenankan eksekusi dapat dijalankan di luar putusan yang telah memperoleh kekuatan hukum tetap, salah satunya Eksekusi atas jaminan fidusia sesuai dengan Undangundang Nomor 42 Tahun 1999 tentang Jaminan Fidusia. Terhadap produk ini, pihak kreditur dapat langsung meminta eksekusi atas objek barang jaminan fidusia apabila debitur melakukan wanprestasi membayar utang, eksekusi dilakukan dengan penjualan melalui lelang karena diperjanjikan klausul kuasa menjual. ${ }^{9}$

\section{Metode Penelitian}

Penelitian ini menggunakan metode pendekatan sosio legal studies. Sosio legal studies mempunyai tujuan akhir yang berkaitan dengan tujuan esensi hukum, melalui peninjauan kembali atau penemuan baru norma hukum yang seharusnya berlaku dan yang seharusnya tidak berlaku. Dalam penelitian ini nantinya, peneliti ingin menemukan esensi keadilan dan ketertiban hukum yang seharusnya dihadirkan dalam hukum di Indonesia yang berkaitan erat dengan masalah hukum pelaksanaan eksekusi jaminan fidusia pasca Putusan Mahkamah Konstitusi Nomor 18/PUU-XVII/2019.

\section{Hasil dan Pembahasan (Rekonstruksi Pelaksanaan Eksekusi Jaminan Fidusia Pasca Putusan Mahkamah Konstitusi Nomor 18/PUU-XVII/2019).}

Sebelum diundangkannya Undang-Undang Nomor 42 Tahun 1999 tentang Jaminan Fidusia, keberadaan praktek fidusia di Indonesia dilandaskan kepada yurisprudensi dari Hoge Raad Belanda yang dikenal sebagai putusan Bier Broumerij Arrest, di mana hakim untuk pertama kali mengesahkan adanya mekanisme penjaminan seperti

\footnotetext{
${ }^{9}$ Etto Sunaryantocs, 2006, Panduan Lelang PUPN, Jakarta, hal.5.
} 
tersebut. Sebelum Undang-undang Jaminan Fidusia sedikit sekali panduan yang dapat dipegang sebagai referensi bagi keberlakuan instrumen fidusia. Ada juga beberapa ketentuan perundang-undangan yang menyinggung fidusia sebagai suatu instrumen jaminan. Meskipun begitu, secara umun tidak ada panduan teknis mengenai pelaksanaan instrumen fidusia tersebut. Lahirnya jaminan fidusia merupakan murni didasarkan pada kententuan Pasal 1320 jo 1338 Kitab UndangUndang Hukum Perdata (selanjutnya disebut KUHPerdata) mengenai kebebasan berkontrak. ${ }^{10}$

Undang-Undang Jaminan Fidusia bertujuan mana kala proses eksekusi dapat dilaksanakan secara cepat dengan proses sederhana, efisien dan mengandung kepastian hukum. Dalam rangka memenuhi tujuan penjaminan khususnya terhadap jaminan fidusia maka UndangUndang Jaminan Fidusia dalam Pasal 15 ayat (3) Undang-Undang Jaminan Fidusia memberi dasar hukum bagi kredit penerima fidusia untuk melaksanakan parate eksekusi. Kekuatan parate eksekusi Jaminan Fidusia adalah langsung dapat dilaksanakan tanpa melalui peradilan dan bersifat final serta mengikat para pihak untuk melaksanakannya. Ketentuan Pasal 29 ayat (1b) Undang-Undang Jaminan Fidusia merupakan pelaksanaan dari pada Pasal 15 ayat (3) sebagaimana sudah diuraikan diatas, kalau kreditur melaksanakan eksekusi berdasarkan kekuasaan sendiri, menjual benda objek jaminan, maka ia melaksanakan itu berdasarkan parate eksekusi dan dengan itu mengambil jalur yang lain dari pada melalui grosse. ${ }^{11}$

Pelaksanaan parate eksekusi tidak melibatkan pengadilan maupun jurusita. Kalau dipenuhi syarat Pasal 29 ayat (1b) Undang-Undang Jaminan Fidusia kreditur bisa langsung menghubungi juru lelang dan

\footnotetext{
${ }^{10}$ Tan Kamello, Hukum Jaminan Fidusia, suatu kebutuhan yang didambakan, Alumni, Bandung, 2014, hlm. 45.

${ }_{11}$ Sri Soedewi,HukumJaminandi Indonesia Pokok-Pokok Hukum Jaminan dan Jaminan Perorangan, BadanPembinaan Hukum Nasional Departemen Kehakiman, Liberty, Yogyakarta, hlm.31.
} 
minta agar benda jaminan dilelang. Yang terpenting bahwa parate eksekusi selalu harus dilaksanakan melalui suatu penjualan dimuka umum atau lelang. Jadi bila orang menjual atas kekuasaan sendiri, itu sama dengan menjual berdasarkan parate eksekusi dan penjualan seperti ini tidak didasarkan atas titel eksekutorial. Lain halnya kalau orang melaksanakan eksekusi berdasarkan grosse atau keputusan pengadilan yang telah mempunyai kekuatan hukum yang tetap, orang melaksanakan penjualan seperti itu berdasarkan titel eksekutorial. ${ }^{12}$

Keistimewaan dari pada hak parate eksekusi kreditur penerima fidusia dalam Pasal 15 ayat (3) Undang-Undang Jaminan Fidusia adalah bahwa ia bisa menjual barang-barang jaminan sesudah debitur pemberi fidusia cedera janji tanpa melalui prosedur penyitaan lebih dahulu, dan karenanya tanpa melibatkan juru sita, tanpa perantara atau ijin Pengadilan, pokoknya seolah-olah ia melelang barangnya sendiri. Bahkan ia tak perlu menggunakan grosse akta Notaris. Hukum eksekusi diatur dalam Kitab Undang-Undang Hukum Acara Perdata, maka disini kreditur penerima fidusia melaksanakan diluar Hukum Acara. Dengan menggunakan sarana parate eksekusi ini kreditur penerima fidusia mempunyai sarana yang lebih murah, lebih sederhana dan lebih siap untuk setiap waktu diterapkan. Itulah sebabnya maka dikatakan bahwa kreditur penerima fidusia mempunyai sarana pengambilan pelunasan yang tidak hanya lebih didahulukan (separatis) tetapi juga lebih sederhana sehingga dikatakan mempunyai sarana eksekusi yang siap ditangan. ${ }^{13}$

Di Indonesia sendiri, tata Cara Pelaksanaan Parate Eksekusi tidak diatur spesifik. Selama ini tata laksana eksekusi barang jaminan biasanya tunduk kepada ketentuan umum hukum pidana dan ketentuan perdata Perbuatan Melawan Hukum. Penarikan paksa benda jaminan bisa dikategorikan sebagai tindak pidana pada Pasal 368 (1) KUHP. Selain itu untuk melaksanakan Pasal 30 Undang-undang Jaminan

$$
\begin{aligned}
& { }^{12} \mathrm{ibid} \\
& { }^{13} \mathrm{ibid}
\end{aligned}
$$


Fidusia maka dapat juga dirujuk Peraturan Kapolri Nomor 8 Tahun 2011 tentang Pengamanan Eksekusi Jaminan Fidusia. Peraturan ini tidak dimaksudkan untuk melibatkan Kepolisian untuk melakukan penarikan, namun tujuan peraturan ini mengatur peran kepolisian sebatas:

a. Terselenggaranya pelaksanaan eksekusi jaminan Fidusia secara aman, tertib, lancar, dan dapat dipertanggungjawabkan; dan

b. Terlindunginya keselamatan dan keamanan Penerima Jaminan Fidusia, Pemberi Jaminan Fidusia, dan/atau masyarakat dari perbuatan yang dapat menimbulkan kerugian harta benda dan/atau keselamatan jiwa. Sementara penarikannya sendiri tetap menjadi tanggung jawab Kreditur.

Kemudian Otoritas Jasa Keuangan mulai mengadakan regulasi tentang tata cara penarikan objek jaminan. Peraturan Otoritas Jasa Keuangan (POJK) Nomor 35/POJK.05/2018 tentang Penyelenggaraan Usaha Perusahaan Pembiayaan. Pasal 29 POJK 035/POJK.05/2018 mengatur bahwa dalam melakukan eksekusi benda jaminan fidusia Perusahaan Pembiayaan wajib memenuhi ketentuan sebagai berikut:

1. Debitur terbukti wanprestasi (yang dimaksud dengan wanprestasi adalah ketidakmampuan debitur untuk memenuhi kewajiban sebagaimana tercantum dalam perjanjian);

2. Debitur sudah diberikan surat peringatan sesuai dengan perjanjian pembiayaan

3. Perusahaan Pembiayaan memiliki sertifikat fidusia.

\section{Pelaksanaan Eksekusi Jaminan Fidusia Menurut Undang Undang Nomor 42 Tahun 1999 Tentang Jaminan Fidusia}

Pelaksanaan eksekusi jaminan fidusia diatur di dalam pasal 29 sampai dengan Pasal 34 Undang-Undang Nomor 42 Tahun 1999 Tentang Jaminan Fidusia. Dimana eksekusi memiliki makna melaksanakan putusan pengadilan, yang tujuannya tidak lain secara 
paksa. Usaha berupa tindakan-tindakan paksa untuk merealisasikan putusan kepada yang berhak menerima dari pihak yang dibebani kewajiban yang merupakan eksekusi. ${ }^{14}$ Sedangkan Jaminan fidusia merupakan hak jaminan atas benda bergerak baik yang berwujud maupun yang tidak berwujud dan benda tidak bergerak khususnya bangunan yang tidak dapat dibebani hak tanggungan sebagaimana dimaksud dalam Undang-undang Nomor 4 Tahun 1996 tentang Hak Tanggungan yang tetap berada dalam penguasaan Pemberi Fidusia, sebagai agunan bagi pelunasan utang tertentu, yang memberikan kedudukan yang diutamakan kepada Penerima Fidusia terhadap kreditur lainnya. ${ }^{15}$ Salah satu cara eksekusi terhadap benda yang menjadi obyek jaminan fidusia dapat dilakukan dengan cara pelaksanaan titel eksekutorial. Sertifikat jaminan fidusia mempunyai kekuatan eksekutorial yang sama dengan putusan pengadilan yang telah memperoleh kekuatan hukum tetap, sehingga ketika debitur cidera janji, kreditur dengan menggunakan sertifikat jaminan fidusia tersebut langsung dapat melaksanakan eksekusi tanpa melalui pengadilan dan bersifat final serta mengikat, para pihak untuk melaksanakan putusan tersebut.

Berikut bunyi pasal-pasal dimaksud:

Pasal 29 Undang-undang No. 42 Tahun 1999 Tentang Jaminan Fidusia

(1) Apabila debitor atau Pemberi Fidusia ciderajanji, eksekusi terhadap Benda yang menjadi objek Jaminan Fidusia dapat dilakukan dengan cara :

a. pelaksanaan titel eksekutorial sebagaimana dimakasud dalam Pasal 15 ayat (2) oleh Penerima Fidusia;

b. penjualan Benda yang menjadi objek Jaminan Fidusia atas kekuasaan Penerima Fidusia sendiri melalui pelelangan umum serta mengambil pelunasan piutangnya dari hasil penjualan;

c. penjualan di bawah tangan yang dilakukan berdasarkan kesepakatan Pemberi dan Penerima Fidusia jika dengan cara

${ }^{14}$ Djazuli Bachar, Eksekusi Putusan Perkara Perdata, Segi Hukum dan Penegakan Hukum, Raja Grafindo Persada, Jakarta, 2000, hlm. 6. angka 2

${ }_{15}$ Undang-Undang Nomor 42 Tahun 1999 Tentang Jaminan Fidusia, Pasal 1 
demikian dapat diperoleh harga tertinggi yang menguntungkan para pihak.

(2) Pelaksanaan penjualan sebagaimana dimaksud dalam ayat (1) huruf c dilakukan setelah lewat waktu 1 (satu) bulan sejak diberitahukan secara tertulis oleh Pemberi dan atau Penerima Fidusia kepada pihak-pihak yang berkepentingan dan diumumkan sedikitnya dalam 2 (dua) surat kabar yang beredar di daerah yang bersangkutan.

Pasal 30 Undang-undang No. 42 Tahun 1999 Tentang Jaminan Fidusia

"Pemberi Fidusia wajib menyerahkan Benda yang menjadi objek Jaminan Fidusia dalam rangka pelaksanaan eksekusi Jaminan Fidusia."

Pasal 31 Undang-undang No. 42 Tahun 1999 Tentang Jaminan Fidusia "Dalam hal Benda yang menjadi objek Jaminan Fidusia terdiri atas benda perdagangan atau efek yang dapat dijual di pasar atau di bursa, penjualannya dapat dilakukan di tempat-tempat tersebut sesuai dengan peraturan perundang- undangan yang berlaku".

Pasal 32 Undang-undang No. 42 Tahun 1999 Tentang Jaminan Fidusia.

"Setiap janji untuk melaksanakan eksekusi terhadap Benda yang menjadi objek Jaminan Fidusia dengan cara yang bertentangan dengan ketentuan sebagaimana dimaksud dalam Pasal 29 dan Pasal 31, batal demi hukum".

Pasal 33 Undang-undang No. 42 Tahun 1999 Tentang Jaminan Fidusia

"Setiap janji yang memberikan kewenangan kepada Penerima Fidusia untuk memiliki Benda yang menjadi objek Jaminan Fidusia apabila debitor cidera janji, batal demi hukum".

Pasal 34 Undang-undang No. 42 Tahun 1999 Tentang Jaminan Fidusia

(1) Dalam hal hasil eksekusi melebihi nilai penjaminan, Penerima Fidusia wajib mengembalikan kelebihan tersebut kepada Pemberi Fidusia.

(2) Apabila hasi eksekusi tidak mencukupi untuk pelunasan utang, debitor tetap bertanggung jawab atas utang yang belum terbayar.

Eksekusi jaminan fidusia adalah penyitaan dan penjualan benda yang menjadi objek jaminan fidusia. Faktor penyebab timbulnya eksekusi jaminan fidusia ini adalah karena pemberi fidusia cidera janji atau tidak 
memenuhi prestasinya tepat pada waktunya kepada penerima fidusia, walaupun mereka telah diberikan somasi. Dari pengaturan pasal-pasal diatas, maka dapat diihat bahwa eksekusi Jaminan Fidusia dapat dilakukan melalui cara-cara, antara lain :

a. Eksekusi langsung dengan titel eksekutorial yang berarti sama kekuatannya dengan putusan pengadilan yang berkekuatan hukum tetap.

Pelaksanaan titel eksekutorial oleh penerima fidusia. Titel eksekutorial yaitu tulisan yang mengandung pelaksanaan putusan pengadilan, yang memberikan dasar untuk penyitaan dan lelang sita (executorial verkoop) tanpa perantara Hakim. Eksekusi ini dibenarkan oleh Undang-undang Nomor 42 Tahun 1999 Tentang Jarminan Fidusia karena menurut pasal 15 ayat (2) Undang-undang Nomor 42 Tahun 1999 Tentang Jaminan Fidusia, sertifikat Jaminan Fidusia menggunakan irahirah "Demi Keadilan Berdasarkan Ketuhanan Yang Maha Esa" yang berarti kekuatannya sama dengan kekuatan putusan pengadilan yang bersifat tetap. Irah-irah ini memberikan titel eksekutorial dan berarti akta tersebut tinggal dieksekusi tanpa harus melalui suatu putusan pengadilan. Karena itu, yang dimaksud dengan fiat eksekusi adalah eksekusi atas sebuah akta seperti mengeksekusi suatu putusan pengadilan yang telah berkekuatan pasti, yakni dengan cara meminta fiat dari ketua pengadilan dengan cara memohon penetapan dari ketua pengadilan untuk melakukan eksekusi. Ketua pengadilan akan memimpin eksekusi sebagai mana dimaksud dalam HIR.

b. Pelelangan Umum.

Eksekusi fidusia juga dapat dilakukan dengan jalan mengeksekusinya, oleh penerima fidusia lewat lembaga pelelangan umum (kantor lelang), di mana hasil pelelangan tersebut diambil untuk melunasi pembayaran tagihan penerima fidusia. Parate eksekusi lewat pelelangan umum ini dapat dilakukan tanpa melibatkan pengadilan sebagaimana 
diatur pasal 29 ayat (1) huruf b Undang-undang Nomor 42 Tahun 1999 Tentang Jaminan Fidusia.

C. Penjualan di bawah tangan.

Penjualan di bawah tangan yang dilakukan berdasarkan kesepakatan pemberi dan penerima fidusia jika dengan cara demikian dapat diperoleh harga yang tertinggi yang menguntungkan para pihak. ${ }^{16}$ Eksekusi fidusia dapat dilakukan melalui penjualan dibawah tangan asalkan terpenuhi syarat-syarat untuk itu. Adapun syarat-syarat tersebut adalah:

1) Dilakukan berdasarkan kesepakatan antara pemberi dengan penerima fidusia.

2) Jika dengan cara penjualan di bawah tangan tersebut dicapai harga tertinggi yang menguntungkan parapihak.

3) Diberitahukan secara tertulis oleh pemberi dan/atau penerima fidusia kepadapihak-pihak yang berkepentingan.

4) Diumumkan dalam sedikitnya dua surat kabar yang beredar di daerah tersebut.

5) Pelaksanaan penjualan dilakukan setelah lewat waktu satu bulan sejak diberitahukan secara tertulis.

d. Eksekusi Secara Mendaku

Eksekusi fidusia dalam cara ini adalah eksekusi dengan cara mengarmbil barang fidusia untuk menjadi milik kreditur secara langsung tanpa lewat suatu transaksi apapun. Namun hal ini dilarang oleh Pasal 33 Undang-Undang Nomor 42 Tahun 1999 Tentang Jaminan Fidusia.

e. Eksekusi terhadap barang perdagangan dan efek yang dapat diperdagangkan.

Eksekusi terhadap barang tersebut dapat dilakukan dengan cara penjualan dipasar atau bursa sesuai dengan ketentuan yang berlaku untuk pasar dan bursa tersebut sesuai dengan maksud pasal 31 UndangUndang Nomor 42 Tahun 1999 Tentang Jaminan Fidusia.

${ }^{16}$ Salim HS, Op.Cit., hlm.89 


\section{f. Eksekusi Lewat Gugatan Biasa.}

MeskipunUndang-Undang Nomor 42 Tahun 1999 Tentang Jaminan Fidusia tidak menyebutkan eksekusi lewat gugatan kepengadilan, tetapi tentunya pihak kreditur dapat menempuh prosedur eksekusi biasa lewat gugatan kepengadilan. Sebab, keberadaan Undang-Undang Nomor 42 Tahun 1999 Tentang Jaminan Fidusia dengan model-model eksekusi khusus tidak untuk meniadakan hukum acara yang umum. Tidak ada indikasi sedikit pun dalam Undang-Undang Nomor 42 Tahun 1999 Tentang Jaminan Fidusia yang bertujuan meniadakan ketentuan hukum acara umum tentang eksekusi umum lewat gugatan kepengadilan negeri yang berwenang.

Sebelum keluarnya Undarg-Undang Jaminan Fidusia, tidak ada kejelasan mengenai bagaimana caranya mengeksekusi objek Jaminan Fidusia. Oleh karena tidak ada ketentuan yang mengaturnya, banyak yang menafsirkan eksekusi objek Jaminan Fidusia dengan memakai prosedur gugatan biasa (lewat pengadilan dengan prosedur biasa) yang panjang, mahal dan melelahkan. ${ }^{17}$ Sehingga dengan lahirnya Undang-Undang Jaminan Fidusia ini semakin mempermudah dan memberi kepastian bagi kreditur dalam pelaksanakan eksekusi. Salah satu ciri Jaminan Fidusia yang kuat itu mudah dan pasti dalam pelaksanaan eksekusinya, jika debitur (pemberi fidusia) cedera janji. ${ }^{18}$

Eksekusi sebagai tindakan hukum yang dilakukan oleh Pengadilan kepada pihak yang kalah dalam suatu perkara merupakan aturan dan tatacara lanjutan dari proses pemeriksaan perkara. Oleh karena itu, eksekusi tiada lain daripada tindakan yang berkesinambungan dari keseluruhan proses hukum acara perdata. Eksekusi merupakan suatu kesatuan yang tidak terpisahkan dari pelaksanaan tata tertib beracara yang terkadung dalam HIR atau Rbg sebagai dasar hukum pelaksanaan eksekusi. Setiap orang yang ingin mengetahui pedoman aturan

17 Rachmadi Usman, Hukum Jaminan Keperdataan, Jakarta: SinarGrafika, 2008,hlm. 229

18 Ibid 
eksekusi harus merujuk ke dalam aturan perundang-undangan dalam HIR atau Rbg. ${ }^{19}$

Eksekusi Jaminan Fidusia dapat dilakukan dalam hal Pemberi Fidusia (debitur) berada dalam dalam keadaan ciderai janji (wanprestasi). Menurut dokrin pengertian wanprestasi adalah "suatu peristiwa atau keadaan dimana debitur tidak memenuhi kewajiban prestasi perikatannya dengan baik dan debitur punya unsur salah atasnya.

Wanprestasi yang dilakukan seseorang debitur berupa :

1. Tidak melakukan apa yang disanggupi akan dilakukannya;

2. Melaksanakan apa yang dijanjikannya, tetapi tidak sebagaimana yang dijanjikan;

3. Melakukan apa yang dijanjikannya tetapi terlambat;

4. Melakukan sesuatu yang menurut perjanjian tidak boleh dilakukannya.

Eksekusi terhadap benda yang menjadi objek jaminan fidusia berdasarkan titel eksekutorial, Pasal 15 ayat (3) jo Pasal 29 ayat (1) b Undang-undanf Jaminan Fidusia memberi kemudahan dalam pelaksanaan eksekusi melalui lembaga parate eksekusi. Kemudian dalam pelaksanaan eksekusi jaminan fidusia tersebut juga dikenal dalam hal gadai sebagaimana di atur dalam Pasal 1155 KUHPerdata. ${ }^{20}$

Secara yuridis penjualan benda jaminan fidusia secara di bawah tangan adalah untuk memperoleh biaya tertinggi dan menguntungkan kedua belah pihak. Oleh karena itu, perlu kesepakatan antara debitur dengan kreditur tentang tata cara menjual benda jaminan fidusia. Misalnya, apakah yang mencari pembeli adalah debitur atau kreditur. Uang hasil penjualan diserahkan kepada kreditur untuk diperhitungkan

19 M. Yahya Harahap, Ruang Lingkup Permasalahan Eksekusi Bidang Perdata, Sinar Grafika, Jakarta, 2005, hlm. 1

${ }^{20}$ Marulak Pardede, Laporan Akhir Penelitian Hukum Tentang Implementasi Jaminan Fidusia Dalam Pemberian Kredit di Indonesia, Badan Pembinaan Hukum Nasional Departemen Hukum dan HAM RI, Jakarta, 2006, hlm. 41 
dengan utang debitur kalau ada sisanya, uang tersebut dikembalikan kepada debitur, akan tetapi jika tidak mencukupi untuk melunasi utang, debitur tetap bertanggung jawab untuk melunasi utangnya. ${ }^{21}$

Di dalam sertifikat jaminan fidusia dicantumkan kata-kata "Demi Keadilan berdasarkan Ketuhanan Yang Maha Esa". Dicantumkannya kalimat tersebut menandakan bahwa sertifikat jaminan fidusia mempunyai kekuatan eksekutorial yang sama dengan putusan pengadilan yang telah memperoleh kekuatan hukum tetap artinya eksekusi langsung dapat dilaksanakan tanpa melalui pengadilan dan bersifat final serta mengikat para pihak untuk melaksanakan putusan tersebut. Demikian juga apabila debitur wanprestasi, maka penerima fidusia mempunyai hak untuk menjual benda yang menjadi objek jaminan fidusia atas kekuasaannya sendiri. $^{22}$

Eksekusi jaminan fidusia didasarkan pada sertifikat jaminan fidusia, sertifikat jaminan fidusia ditertibkan dan diserahkan oleh Kantor Pendaftaran Fidusia kepada Penerima jaminan fidusia memuat tanggal yang sama dengan tanggal penerimaan pendaftaran jaminan fidusia, sertifikat jaminan fidusia merupakan salinan dari Buku Daftar Fidusia, memuat catatan tentang hal-hal yang dinyatakan dalam pendaftaran jaminan fidusia. ${ }^{23}$

\section{Rekonstruksi Pelaksanaan Eksekusi Jaminan Fidusia Pasca} Putusan Mahkamah Konstitusi Nomor 18/PUU-XVII/2019

Mahkamah Konstitusi melalui putusan Nomor 18/PUU-XVII/2019, menyatakan keberlakuan Pasal 15 ayat (2) Undang-Undang Nomor 42 Tahun 1999 tentang Jaminan Fidusia, sepanjang frasa "kekuatan eksekutorial" dan frasa "sama dengan putusan pengadilan yang

${ }^{21}$ Tan Kamello, Op.Cit., hlm. 358

${ }^{22}$ Frieda Husni Hasbullah, Hukum Kebendaan Perdata Hak-Hak Yang Memberi Jaminan, Indhill, Jakarta, 2009, hlm. 87

${ }^{23}$ Gunawan Widjaya dan Ahmad Yani, Jaminan Fidusia, Raja Grafindo Persada, Jakarta, 2001, hlm. 159 
berkekuatan hukum tetap" bertentangan dengan Undang-Undang Dasar Negara Tahun 1945 dan tidak mempunyai kekuatan hukum mengikat. Hal ini sepanjang tidak dimaknai "terhadap jaminan fidusia yang tidak ada kesepakatan tentang cidera janji (wanprestasi) dan debitur keberatan menyerahkan secara sukarela objek yang menjadi jaminan fidusia, maka segala mekanisme dan prosedur hukum dalam pelaksanaan eksekusi Sertifikat Jaminan Fidusia harus dilakukan dan berlaku sama dengan pelaksanaan eksekusi putusan pengadilan yang telah berkekuatan hukum tetap". ${ }^{24}$

Tidak hanya itu, terhadap frasa "cidera janji" sebagaimana diatur dalam Pasal 15 ayat (3) UU Jaminan Fidusia, Mahkamah juga menyatakan frasa "cidera janji" tersebut bertentangan dengan UndangUndang Dasar Tahun 1945 dan tidak mempunyai kekuatan hukum mengikat sepanjang tidak dimaknai bahwa "adanya cidera janji tidak ditentukan secara sepihak oleh kreditur melainkan atas dasar kesepakatan antara kreditur dengan debitur atau atas dasar upaya hukum yang menentukan telah terjadinya cidera janji”. ${ }^{25}$

Ada beberapa hal yang terjadi setelah putusan ini dikabulkan sebagai berikut:

1. Berkurangnya kekuatan eksekutorial sertifikat jaminan fidusia

Pasal 15 ayat (2) mengatur bahwa ketentuan pemberian irah-irah demi Keadilan Yang Berketuhanan Yang Masa Esa dan selanjutnya mempunyai kekuatan eksekutorial yang sama dengan putusan pengadilan yang telah memperoleh kekuatan hukum tetap menjadi berkurang. Perlu dipahami bahwa hakekat titel eksekutorial adalah kekuatan untuk dilaksanakan secara paksa dengan bantuan dan oleh alat-alat negara. Mekanisme pelaksanaan titel eksekutorial sendiri dilakukan dengan meminta ijin Ketua Pengadilan, yang kemudian

\footnotetext{
${ }_{25}^{24}$ Lihat Putusan Mahkamah Konstitusi Nomor 18/PUU-XVII/2019

${ }^{25}$ Ibid
} 
dilanjutkan dengan mekanisme aanmaning, sampai akhirnya dilanjutkan dengan sita eksekusi dan penjualan.

Artinya apabila pasal ini dihilangkan, maka pemegang jaminan fidusia tidak lagi dapat mengajukan permohonan eksekusi ke pengadilan, dan oleh karenanya harus terlebih dulu memperoleh putusan berkekuatan hukum tetap melalui gugatan wanprestasi terhadap debitur, sebelum dapat mengajukan titel eksekutorialnya.

2. Hapusnya mekanisme parate eksekusi atas jaminan Fidusia

Penghapusan kalimat cidera janji, sepanjang tidak dimaknai "dalam hal penentuan adanya tindakan "cidera janji" dapat dilakukan oleh Penerima Fidusia (Kreditur) dalam hal tidak ada keberatan dan melakukan upaya hukum, atau paling tidak dalam hal adanya upaya hukum maka melalui putusan pengadilan berkekuatan hukum tetap, berpotensi untuk menghilangkan sifat utama jaminan fidusia, yaitu kemudahan eksekusinya. Akibatnya apabila terjadi cidera janji yang diperdebatkan oleh Debitur atas alasan apapun, jalan yang tersedia hanyalah melakukan gugatan wanprestasi.

Undang- undang Jaminan Fidusia memberikan kemudahan bagi kreditur untuk melakukan eksekusi dalam hal debitur cidera janji, sebagai salah satu cirinya. Dalam hal terjadi cidera janji, maka berdasarkan Pasal 15 (3) Undang- undang Jaminan Fidusia kreditur diperkenankan atas kekuasaannya sendiri untuk melakukan penjualan atas benda jaminan. Hal ini dapat dipahami, mengingat benda bergerak memiliki karakter yang berbeda dengan benda tidak bergerak. Benda bergerak memiliki sifat mudah dipindah tangankan, dan mudah dipisah-diganti.

Selain itu perlu juga dipahami bahwa benda bergerak yang dijaminkan biasanya memiliki nilai yang tidak besar, oleh karenanya biaya untuk melakukan pembebanan jaminan fidusia, termasuk eksekusinya juga harus dipertimbangkan sematang-matangnya, supaya tetap efisien. 
Lebih jauh lagi, sebagian jenis benda bergerak memiliki sifat mudah rusak, sehingga apabila pengaturan eksekusi jaminan benda bergerak mengharuskan prosedural yang berlarut-larut, maka ada potensi bahwa benda jaminan akan mengalami hilang, rusak, atau hal lain yang mengakibatkan penurunan nilai, yang tentunya merugikan Kreditur. Perlindungan Kreditur sendiri juga penting, karena bagi benda bergerak berlaku prinsip Pasal 1977 KUH Perdata yang mengatakan bahwa penguasaan atas benda bergerak berlaku sebagai titel yang sempurna.

Sehingga keistimewaan- keistimewaan yang diberikan kepada Kreditur memang dibuat sedemikian rupa oleh undang-undang untuk mengkompensasi keterbatasan sifat jaminan kebendaan pada benda bergerak tanpa penguasaan. Tanpa adanya mekanisme untuk melakukan eksekusi secara cepat, sederhana dan murah justru bertentangan dengan kebutuhan dunia usaha, yang berisiko tidak terbentuknya pembiayaan yang murah bagi debitur.

Dalam pelaksanaan eksekusi, ${ }^{26}$ terdapat tahap-tahap yang dilakukan sebagai berikut:

a. Adanya permohonan eksekusi

Setelah adanya putuan pengadilan yang telah berkekuatan hukum tetap maka pada dasarnya pemenuhan amar putusan tersebut harus dilaksanakan oleh pihak yang kalah secara sukarela. Eksekusi akan dapat dijalankan apabila pihak yang kalah tidak menjalankan putuan dengan sukarela, dengan mengajukan permohonan eksekusi oleh pihak yang menang kepada Ketua Pengadilan Negeri yang berwenang.

\section{b. Aanmaning}

Permohonan eksekusi merupakan dasar bagi Ketua Pengadilan Negeri untuk melakukan peringatan atau aanmaning. Aanmaning merupakan tindakan dan upaya yang dilakukan Ketua Pengadilan Negeri yang memutus perkara berupa "teguran" kepada Tergugat (yang kalah)

\footnotetext{
${ }^{26}$ http://pn-karanganyar.go.id/main/index.php/berita/artikel/993-eksekusi
} 
agar ia menjalankan isi putusan secara sukarela dalam waktu yang ditentukan setelah Ketua Pengadilan menerima permohonan eksekusi dari Penggugat. Pihak yang kalah diberikan jangka waktu 8 (delapan) hari untuk melaksanakan isi putusan terhitung sejak debitur dipanggil untuk menghadap guna diberikan peringatan.

c. Permohonan sita eksekusi

Setelah aanmaning dilakukan, ternyata pihak yang kalah tidak juga melakukan amar dari putusan maka pengadilan melakukan sita eksekusi terhadap harta pihak yang kalah berdasarkan permohonan dari pihak yang menang. Permohonan tersebut menjadi dasar bagi Pengadilan untuk mengeluarkan Surat Penetapan yang berisi perintah kepada Panitera atau Juru Sita untuk melakukan sita eksekusi terhadap harta kekayaan tergugat, sesuai dengan syarat dan tata cara yang diatur dalam Pasal 197 HIR. Penetapan sita eksekusi merupakan lanjutan dari penetapan aanmaning. Secara garis besar terdapat 2 (dua) macam cara peletakan sita yaitu sita jaminan dan sita eksekusi. Sita jaminan mengandung arti bahwa, untuk menjamin pelaksanaan suatu putusan di kemudian hari, barang-barang yang disita tidak dapat dialihkan, diperjualbelikan atau dengan jalan lain dipindah tangankan kepada orang lain. Sedangkan sita eksekusi adalah sita yang ditetapkan dan dilaksanakan setelah suatu perkara mempunyai putusan yang mempunyai kekuatan hukum tetap.

\section{d. Penetapan eksekusi}

Setelah adanya permohonan sita eksekusi maka tahap selanjutnya adalah dikeluarkannya Penetapan Eksekusi yang berisi perintah Ketua Pengadilan Negeri kepada Panitera dan juru sita untuk menjalankan eksekusi.

\section{e. Lelang}

Setelah Pengadilan mengeluarkan Penetapan Eksekusi berikut Berita Acara Eksekusi maka tahap selanjutnya adalah lelang. Lelang merupakan penjualan di muka umum harta kekayaan termohon yang telah 
disita eksekusi atau menjual di muka umum barang sitaan milik termohon yang dilakukan di depan juru lelang atau penjualan lelang dilakukan dengan perantaraan atau bantuan kantor lelang dan cara penjualannnya dengan jalan harga penawaran semakin meningkat atau semakin menurun melalui penawaran secara tertulis (penawaran dengan pendaftaran). Tujuan lelang ini adalah untuk pemenuhan kewajiban si tergugat. Penggunaan kantor lelang dimaksudkan agar harga yang didapat tidak merugikan si tergugat dan sesuai dengan harga yang sewajarnya di pasaran. Hasil lelang digunakan untuk membayar kewajiban yang telah ditetapkan dalam putusan hakim.

\section{Kesimpulan dan Saran}

\section{Kesimpulan}

Bahwa Rekonstruksi Pelaksanaan Eksekusi Jaminan Fidusia Pasca Putusan Mahkamah Konstitusi Nomor 18/PUU-XVII/2019 sepanjang pemberi hak fidusia (debitur) telah mengakui adanya "cidera janji" (wanprestasi) dan secara sukarela menyerahkan benda yang menjadi objek dalam perjanjian fidusia, maka menjadi kewenangan sepenuhnya bagi penerima fidusia (kreditur) untuk dapat melakukan eksekusi sendiri (parate eksekusi). Namun, apabila yang terjadi sebaliknya, di mana pemberi hak fidusia (debitur) tidak mengakui adanya "cidera janji" (wanprestasi) dan keberatan untuk menyerahkan secara sukarela benda yang menjadi objek dalam perjanjian fidusia, maka penerima hak fidusia (kreditur) tidak boleh melakukan eksekusi sendiri melainkan harus mengajukan permohonan pelaksanaan eksekusi kepada pengadilan negeri. Dengan demikian hak pemberi hak fidusia (debitur) dan penerima hak fidusia (kreditur) terlindungi secara seimbang. 


\section{Saran}

Pemerintah ke depan mesti melakukan penataan dengan segera untuk memberikan kepastian terhadap dunia usaha dengan membawa konsep baru menyusul terbitnya putusan Mahkamah Konstitusi Nomor 18/PUU-XVII/2019. Kemudian dengan terbitnya putusan ini, dunia usaha akan menemukan hambatan mengingat proses untuk mengeksekusi dan menjual benda yang merupakan Jaminan Fidusia, tidak semudah sebelum keluarnya putusan Mahkamah Konstitusi Nomor 18/PUU-XVII/2019. 


\section{DAFTAR PUSTAKA}

Djazuli Bachar, Eksekusi Putusan Perkara Perdata, Segi Hukum dan Penegakan Hukum, Raja Grafindo Persada, Jakarta, 2000.

Etto Sunaryantocs, Panduan Lelang PUPN, Jakarta, 2006.

Frieda Husni Hasbullah, Hukum Kebendaan Perdata Hak-Hak Yang Memberi Jaminan, Indhill, Jakarta, 2009.

GunawanWidjaya dan Ahmad Yani, Jaminan Fidusia, Raja Grafindo Persada, Jakarta, 2001.

Herowati Poesoko, Parate Executie Obyek Hak Tanggungan, Yogyakarta: Laksbang Pressindo, 2008.

Khotibul Umam, Hukum Lembaga Pembiayaan, Pustaka Yustisia, Yogyakarta, 2010.

Marulak Pardede, Laporan Akhir Penelitian Hukum Tentang Implementasi Jaminan Fidusia Dalam Pemberian Kredit di Indonesia, Badan Pembinaan Hukum Nasional Departemen Hukum dan HAM RI, Jakarta, 2006.

M. Yahya Harahap, Ruang Lingkup Permasalahan Eksekusi Bidang Perdata, Sinar Grafika, Jakarta, 2005.

Rachmadi Usman, Hukum Jaminan Keperdataan, Jakarta Sinar Grafika, 2008.

Salim HS, Perkembangan Hukum Jaminan di Indonesia, Raja Grafindo Persada, Jakarta, 2008.

Shavira Ramadhanneswari, "Penarikan Kendaraan Bermotor Oleh Perusahaan Pembiayaan Terhadap Debitur Yang Mengalami Kredit Macet (Wanprestasi) Dengan Jaminan Fidusia Ditinjau Dari Aspek Yuridis" Jurnal IImiah Fakultas Hukum, Universitas Diponegoro, 2017.

Sunaryo, Hukum Lembaga Pembiayaan, Sinar Grafika, Jakarta, 2007.

Sri Soedewi, Hukum Jaminan di Indonesia Pokok-Pokok Hukum Jaminan dan Jaminan Perorangan, Badan Pembinaan Hukum Nasional Departemen Kehakiman, Liberty, Yogyakarta.

Tan Kamello, Hukum Jaminan Fidusia, suatu kebutuhan yang didambakan, Alumni, Bandung, 2014.

Undang-Undang Nomor 42 Tahun 1999 tentang Jaminan Fidusia

Peraturan Kapolri Nomor 8 Tahun 2011 tentang Pengamanan Eksekusi Jaminan Fidusia.

Peraturan Otoritas Jasa Keuangan Nomor 35/POJK.05/2018 tentang Penyelenggaraan Usaha Perusahaan Pembiayaan

Putusan Mahkamah Konstitusi Nomor 18/PUU-XVII/2019

http://pn-karanganyar.go.id/main/index.php/berita/artikel/993-eksekusi 